\title{
Isolation and characterization of bacteria isolated from municipal solid waste for production of industrial enzymes and waste degradation
}

\begin{abstract}
A total of 10 samples were collected from waste dump sites of Dhapa and Barrackpore Municipality and 9 isolates of bacteria were isolated using Nutrient Agar medium. The optimal cultural conditions, microbiological characteristics, biochemical characteristics, antagonistic and synergistic activities within the strains, tolerance to 5 heavy metals (arsenic, zinc, lead, mercury, and cadmium), their sensitivity towards four different antibiotics (gentamycin, oxytetracycline, penicillin, streptomycin) and production of extracellular enzyme of the bacterial strains were documented. Among the 9 isolates 6 exhibited protease production and 1 was selected for protease production with high titer value. All of the 6 strains capable of producing protease were also applied for waste degradation efficiency test. These results have increased the scope of finding industrially important bacteria from municipal waste dump sites and these isolates could be vital source for the discovery of industrially useful enzymes/molecules.
\end{abstract}

Keywords: waste dump sites, bacteria, antagonism, extracellular enzymes
Volume I Issue I - 2014

\author{
Amrita Saha, Subhas Chandra Santra \\ Department of Environmental Science, University of Kalyani, \\ India
}

Correspondence: Amrita Saha, Department of Environmental Science, University of Kalyani, Kalyani-74I 235, Nadia, West Bengal, India, Tel +9l-9830535722, Email asmicrobio@yahoo.in

Received: April 18, 2014 | Published: May 07, 2014

\section{Introduction}

Waste generation and its control have taken an important role in our environment. With the doubling of population and changing lifestyle pattern of the inhabitants the quantity of municipal waste generated is increasing in an alarming rate. Most of this waste is subjected to dumping in a specified disposal yard. The greatest challenge to the environmentalists is the eco friendly management of this waste and application of microorganisms in this context has got an age over other available technologies. Organic waste is consumed by the bacteria, used as nutrients by the bacteria, and is no longer present to produce odors, sludge, pollution or unsightly mess. When bacteria consume waste, they convert the waste into safe by products and in due course of this conversion they actually produce several metabolites to break down the complex waste into simple compounds. Soil microorganisms are increasingly becoming an important source in the search for industrially important molecules. ${ }^{1}$ Extent of microbial diversity in nature is still largely unknown, thus there might be many more useful products yet to be identified from soil microorganisms. In soil 80 to $99 \%$ of microorganisms remain unidentified whereas these biological communities are known to play a dominant role in maintaining a sustainable biosphere. Today both academic and industrial interest in soil bacteria (due to their several advantages over other microorganisms) is on the rise, in search of deriving these unique biologically active metabolites and novel commercially important products from them. Bacteria are present in diverse ecological habitats. They are considered highly valuable as they are used in fermentation processes, much as brewing, baking, cheese and butter manufacturing, chemical manufacturing such as ethanol, acetone, organic acid, enzymes, perfumes etc., microbial mining and they produce various antibiotics, vaccines, steroids as well as other therapeutically useful compounds with diverse biological activities. Hence there is an immense possibility to screen effective bacterial strains from waste dump sites with valuable applications.
To cope up with the demand for new organisms with properties of production of unique enzymes/molecules for industrial application and waste degradation there have been a constant effort in isolating novel bacteria from diverse environment. Accordingly, the present study was aimed to investigate bacterial strains from waste dump sites with the ultimate objective of waste degradation and discovering novel bioactive compounds for industrial application.

\section{Materials and methods}

\section{Study area}

Soil sample was collected from waste disposal site of Barrackpore Municipality in Barrackpore (latitude 22 ${ }^{\circ} 44^{\prime} \mathrm{N}$ and longitude $88^{\circ} 30^{\prime} \mathrm{E}$ ) in North 24 Parganas District of West Bengal State in Eastern India and from Dhapa situated at $88^{\circ} 20^{\prime} \mathrm{E}-88^{\circ} 35^{\prime} \mathrm{E}$ and $20^{\circ} 25^{\prime} \mathrm{N}-20^{\circ} 35^{\prime} \mathrm{N}$ at Kolkata District in West Bengal.

\section{Collection of samples}

A total of 10 waste samples were collected 5 from waste disposal site of Barrackpore Municipality and rest 5 from Dhapa, landfill site of city of Kolkata. Sample (soil mixed with waste) was collected in sterile zip-lock plastic maintaining aseptic conditions, stored at $4{ }^{\circ} \mathrm{C}$ and marked accordingly to their source and location. The collected samples were brought to the laboratory for isolation of soil bacteria and the moisture content and $\mathrm{pH}$ of sample were documented.

\section{Determination of moisture content (\%) and $\mathrm{pH}$ of waste samples}

Freshly collected samples were kept in filter paper and the initial weight was recorded. After that these samples were kept inside a hot air incubator at $110{ }^{\circ} \mathrm{C}$. The samples were weighed several times until a constant weight was achieved. Samples moisture content was calculated employing the following formula provided by AWPA. ${ }^{2}$ 


$$
M C(\%)=W-w w X 100
$$

Where, $\mathrm{MC}$ is moisture content, $\mathrm{W}$ is the original weight and $\mathrm{w}$ is the constant weight after oven drying. $\mathrm{pH}$ was determined in Electrometric method with the help of a $\mathrm{pH}$ meter using combination glass electrode.

\section{Chemical analysis of waste}

Chemical characteristic of sample were analyzed for the following properties: Organic matter $(\%)$, total $\mathrm{N}(\%), \mathrm{P}(\%)$ and $\mathrm{K}(\%)$. Organic carbon was determined following a rapid titration method Walkey et al. ${ }^{3}$ Determination of total Nitrogen content was performed by digestion of the waste with a mixture of acids $\left(\mathrm{HClO}_{4}, \mathrm{HNO}_{3}, \mathrm{H}_{2} \mathrm{SO}_{4}\right)$ and then using Kjeldahl procedure according to the method described by Bremner. ${ }^{4}$ Total Phosphorous was estimated by Colorimetric method using ammonium molybdate and stannous chloride. Total Potassium was estimated by Flame photometric method. ${ }^{5}$

\section{Isolation of bacteria from waste samples}

Serial dilution techniques were used for the isolation of bacteria In this technique sample suspension was prepared by adding soil mixed with waste $(1 \mathrm{~g})$ was added to $10 \mathrm{ml}$ of sterile water (the stock) and shaken vigorously for at least 1 minute. The dilute was then sedimented for a short period. Sterile dilution blanks were marked sequentially starting from stock and $10^{-1}$ to $10^{-4}$. One $\mathrm{ml}$ from the stock was transferred to the $10^{-1}$ dilution blank using a fresh sterile pipette. One $\mathrm{ml}$ from the $10^{-1}$ dilution was transferred to the $10^{-2}$ tube for each succeeding step then from the $10^{-2}$ to the $10-3$, then from the $10-3$ to the $10^{-4}$. From each dilution tube $0.1 \mathrm{ml}$ of dilution fluid was transferred into Nutrient Agar culture media and incubated at $37^{\circ} \mathrm{C}$ for 24hours. Nutrient Agar (NA) culture media contained $0.5 \%$ peptone, $0.3 \%$ yeast extract, $0.5 \% \mathrm{NaCl}, 0.25 \%$ glucose, $1.5 \%$ agar, distilled water and $\mathrm{pH}$ was adjusted to 7 at room temperature. After successful growth of microorganisms the pure cultures of bacteria were subcultured in NA slants; incubated at $37^{\circ} \mathrm{C}$ to achieve vigorous growth and then preserved in $20 \%$ glycerol vials at $-80^{\circ} \mathrm{C}$.

\section{Microbiological and biochemical characteristic of isolated bacteria}

Gram stain was performed to observe the cellular morphology and gram nature of the bacteria and biochemical characterization of the strains were also carried out. The biochemical tests of Sugar utilization; Amino acid decarboxylation; Catalase and oxidase production; Nitrate reduction; Hydrogen sulfide production; Starch, Casein and Urea hydrolysis; IMVIC tests were performed. ${ }^{7,8}$

\section{Optimization of growth condition}

Three semi-solid media as NA (Nutrient Agar), BCDA (czapek dox agar medium (Basic)) and ACDA (Czapek Dox Agar medium (Acidic)) were used to optimize the cultural media of isolated bacteria. The $\mathrm{pH}$ were adjusted to 5.2, 6.5, 7.2, 8.9 and 10.2 in NA medium; 2.2, 3.2, 4.0, 5.5 and 6.9 in BCDA medium; and 7.1, 7.6, 9.1, 10.06 and 12.10 in ACDA medium. For optimization of incubation period and temperature the culture plates were incubated at 25, 29,33, 37 and $41^{\circ} \mathrm{C}$ for $6-72$ hours

\section{Antagonism of bacterial strains}

Each strain was grown at room temperature and subsequently tested by the cross-streaking method at room temperature and at $37^{\circ} \mathrm{C}$. The cross-streaking method was performed as described by Gillers \& Govan..$^{910}$ with two modifications. The strain to be tested was inoculated as a $1.5 \mathrm{~cm}$-wide streak (instead of $1 \mathrm{~cm}$ ) diametrically across duplicate nutrient agar plates. The plates were incubated overnight at either room temperature or $37^{\circ} \mathrm{C}$. A wider streak of the original inoculum was used because the inhibitory zones produced were larger and clearer. After overnight incubation, the inoculum was removed with a glass slide, and remaining viable growth was killed by exposure to UV light for $30 \mathrm{~min}$. The indicator strains were streaked singly at right angles to the original inoculum by using a wire loop (8 strains per plate). The plates were incubated at room temperature or $37^{\circ} \mathrm{C}$ overnight, and inhibition was recorded where the indicator strains crossed the original inoculum. This procedure was followed until each of the strains had been tested against each other.

\section{Metal tolerance assay}

Study of MIC (Minimum Inhibitory Concentration) of heavy metals viz. Arsenic (As), Zinc ( $\mathrm{Zn})$, Lead (Pb), Cadmium (Cd) and Mercury $(\mathrm{Hg})$ was carried out for the bacterial strains through Cup Assay method. The sterilized agar medium (Beef extract-10gm, Peptone-10gm, Sodium chloride-5 gm, Glucose-1gm, Agar-20gm per litre of distilled water, $\mathrm{pH}-7.5$ ) was prepared for bacterial growth The plates were inoculated with bacterial suspension through spread plate method. On each plate cups were made by sterilized cup borer. Various concentrations of each metal compounds poured on cups of pre-inoculated plates. For each metal concentration separate Petri plate with pre-inoculated bacteria were used. All the plates were incubated at $37 \pm 2^{\circ} \mathrm{C}$ for 48 hours. The diameters (milimetre) of inhibition zone around each cup were measured against each concentration and also against each bacterium. Plates without any metal concentration were treated as reference plates.

\section{Antibiotic sensitivity assay}

The cup assay method ${ }^{11}$ was used for antibiotic sensitivity testing. The sterilized agar medium (Beef extract-10gm, Peptone$10 \mathrm{gm}$, Sodium chloride- $5 \mathrm{gm}$, Glucose-1 gm, Agar-20 gm per litre of distilled water, $\mathrm{pH}-7.5)$ was prepared for bacterial growth. The plates were inoculated with bacterial suspension through spread plate method. On each plate cups were made by sterilized cup borer. A constant concentration of $100 \mathrm{ppm}$ of each antibiotic (gentamycin, oxytetracycline, penicillin, and Streptomycin) was poured on cups of pre-inoculated plates. For each antibiotic concentration separate petri plate with pre-inoculated bacteria were used. All the plates were incubated at $37 \pm 2^{\circ} \mathrm{C}$ for 48 hours. The inhibition zone around each cup was observed against each antibiotic and also against each bacterium. Plates without any antibiotic concentration were treated as reference plates.

\section{Antimicrobial activity}

The search for new antimicrobial agents is a field of utmost importance. The prevalence of antimicrobial resistance among key microbial pathogens is increasing at an alarming rate worldwide. All the 9 isolates were screened for antibacterial and antifungal activity by cross streak method. ${ }^{12}$ In the cross streak method, the soil isolates were streaked on modified nutrient agar as a straight line in the left side corner of the Petri plate and the plates were incubated overnight at either room temperature or $37^{\circ} \mathrm{C}$. After incubation, the test human bacterial pathogens (Klebsiella pneumoniae, Staphylococcus aureus, and Salmonella sp.) and fungal pathogens (Fusarium sp., Alternaria 
sp., Helminthosporium sp.) were streaked at right angle to the original streak of the bacterial isolates. The zone of inhibition against human bacterial pathogens and fungal pathogens were observed after $48 \mathrm{~h}$ of incubation. Plates with the same medium without inoculation of bacterial isolates but with simultaneous streaking of test organisms were maintained for controls.

\section{Extracellular enzyme production}

All the isolated bacterial strains were screened qualitatively for the production of eight important enzymes such as protease, lecithinase, DNase, lipase, cellulase, amylase, catalase, and oxidase. Each bacterial strain was streaked on the four corners of the respective substrates such as milk, egg yolk, toluidine, tributyrin, casein, tween 80 amended agar plates separately and for catalase and oxidase discs were used. The Petri plates were incubated overnight at either room temperature or $37^{\circ} \mathrm{C}$. Then the plates were flooded with indicator solution and the development of clear zone around the growth of organism was considered positive for enzyme activity.

\section{Protease activity}

In keeping with the due potential of protease enzyme in waste degradation and industrial application, assay of protease activity was also carried out for 6 strains producing protease among the 9 isolates. Protease activity was determined by Caseinolytic method. ${ }^{13}$ One unit (U) of enzyme is defined as the amount of protease that liberates peptide fragments equivalent to one $\mathrm{mg}$ of bovine serum albumin (BSA) per unit time (min-1) under the assay conditions. ${ }^{14}$

\section{Waste degradation potential of selected bacterial samples}

24hours of old bacterial culture in tube $10 \mathrm{ml}$ of autoclaved distilled water was added and then mixed well for making a suspension. After that the sterilized garbage was inoculated with $5 \mathrm{ml}$ of this bacterial suspension and mixed well. Control treatments were also performed with inoculation.

The Waste Degradation Potential of Bacteria was studied by weight loss method. Litter sample was collected in sterile litter bags under aseptic condition. Collected samples were brought to the laboratory and then sterilized in autoclave at $121^{\circ} \mathrm{C}$ (at $15 \mathrm{lb} / \mathrm{inch}^{2}$ for 15 minutes. Sterilized waste samples were then weighed and inoculated with isolated bacteria and kept at $38^{\circ} \mathrm{C}$ for 7 days, 15 days and 21 days respectively. After definite period of incubation waste samples were washed with sterile water to remove inoculated microorganisms, and then they are dried and weighed. The weight loss was calculated and from that very data the degradation potential of bacteria was determined.

\section{Results and discussion}

The isolation and characterization of bacterial strains from Barrackpore Municipality and Dhapa waste dump site was undertaken in this study. Bacterial growth depends upon various physicochemical conditions such as media, $\mathrm{pH}$, temperature, incubation period, carbon source etc. So different conditions upon which bacteria grew in natural habitat should be studied before going to massive multiplication for using as decomposer. Thus the following parameters were taken into consideration:

\section{Physical and chemical characteristics of municipal solid waste}

Bacteria can grow in a wide range of moisture level. In this study, it was found that the moisture content of the collected sample from Barrackpore Municipality and Dhapa waste dump site was about $65.32 \%$ and $66.45 \%$ respectively. Bacterial population of various soils is closely correlated with their moisture content. The maximum bacterial density is found in regions of fairly high moisture content and the optimum level for the activities of aerobic bacteria often is a $50 \%-75 \%$ of the soil moisture holding capacity. ${ }^{1}$ Numbers of the genera Pseudomonas, Achromobacter and Bacillus are found in most aerobic soils; where conditions are anaerobic and moist Clostridium will occur. Actinomycetes showed a similar quantitative increase under such conditions. ${ }^{15}$

In this study the $\mathrm{pH}$ of the two selected media (BCDA and NA) was optimized for culturing bacterial strains. The ph of the collected sample was 7.79 in both of the samples. The $\mathrm{pH}$ is a key factor for growing bacteria in artificial media. Optimization of $\mathrm{pH}$ was carried out in two selected media viz. Nutrient Agar (NA) And Basic czapek dox agar (BCDA). NA and BCDA at pH 7.2 and 7.6 were found to be suitable for the maximum growth of the bacterial strains. From the results, it was found that the $\mathrm{pH}$ of the sample was about 7.79 and possible for this reason, these strains were also found to grow well in, in vitro condition at $\mathrm{pH}$ 7-8 in BCDA and NA. Bacteria can tolerate a soil reaction between $\mathrm{pH}$ levels 4 and 10 , but the most favorable $\mathrm{pH}$ for the majority is just an alkaline side to neutrality. Bacteria such as Thiobacillus thiooxidans and Acetobacter sp. are capable of growing at the very low $\mathrm{pH}$ values between $\mathrm{pH}$ level 0 and 2 and some Bacillus $s p$. can grow at $\mathrm{pH} 11 .{ }^{15}$ Optimal growth of Thermoactinomycetes occurs at $\mathrm{pH} 8$ or 9 and is greatly depressed by reactions of around $\mathrm{pH}$ $5^{16}$ Vibrio, Streptococcus faecalis and Escherichia coli also tolerate an alkaline reaction $(\mathrm{pH} 8-9){ }^{16}$

The NPK content of the sample was studied initially. The organic matter content was found to be $27.84 \%$ (Barrackpore Municipality) and $29.32 \%$ (Dhapa), Nitrogen Content in \% was 0.165 (Barrackpore Municipality) and 0.179 (Dhapa), Phosphorous Content in \% was 0.502 (Barrackpore Municipality) and 0.545 (Dhapa) and Potassium Content in \% was 18.29 (Barrackpore Municipality) and 19.21 (Dhapa). All these analysis gave a clear understanding of the native environment of the bacteria and thus was the determining factors in the isolation and culture of the strains.

\section{Cultural characteristics of bacterial isolates}

In our study, BM1, BM2, BM3, D1, D2, D3, D4, C2 and C3 -these 9 bacterial strains were isolated in culture media. Czapek dox agar and Nutrient agar were selected to determine the best suitable media for ensuring massive growth of the isolated strains. czapek dox agar (BCDA) was suitable for massive growth of BM3, D1,C2 and Nutrient agar (NA) medium was suitable for massive growth of BM1, BM2, $\mathrm{D} 2, \mathrm{D} 3, \mathrm{D} 4, \mathrm{C} 3$. It was seen that yeast extract xylan containing media was suitable for maximum growth of bacteria but Pseudomonas sp., Bacillus spp., Aeromonas sp. grow well in nutrient agar media. Visual and microscopic observation was used to characterize the selected strains. Details of the colony features of the bacteria are noted (Table 1). Gram staining is an old and reliable method for observing the bacteria. Gram negative bacteria were decolorized by alcohol, losing the purple colour of crystal violet. Gram positive bacteria did not decolorized and remained purple.

In the present investigation, BM1, BM2, BM3, D1, D2, D3, D4, C2 and $\mathrm{C} 3$-these 9 bacterial strains were isolated and the microbiological characterization was carried out. The results showed that BM1, BM3, D1 are gram Positive bacilli, BM2 is gram positive short bacilli, D2 is gram positive diplobacilli, D3, C2 are gram negative bacilli, D4 is 
gram negative short bacilli and C3 is gram positive coccus. Different biochemical tests were also performed for the 9 isolates to know their biochemical characteristics. Details of the biochemical characters of the bacteria are noted in (Table 2).
The above results gave an idea of the morphology, colony characteristics and biochemical nature of the isolated strains which would aid in the identification and characterization of the isolated bacterial strains in future.

Table I Colony features of isolated bacteria

\begin{tabular}{|c|c|c|c|c|}
\hline Strain no & \multicolumn{2}{|l|}{ Colony features } & \multicolumn{2}{|l|}{ Cell features } \\
\hline BMI & White & Irregular, boil like, having secretion within & Gram Positive & Bacilli \\
\hline BM2 & Cream & round shaped, transparent & Gram positive & Short bacilli \\
\hline BM3 & Cream & Irregular, transparent & Gram positive & Bacilli \\
\hline D2 & White & Irregular, boil like, shrinked & Gram positive & Diplobacilli \\
\hline D3 & Cream & Round shaped, slimy growth & Gram negative & Bacilli \\
\hline D4 & Cream & Irregular, boil like, having secretion within & Gram negative & Short bacilli \\
\hline
\end{tabular}

Table 2 Biochemical characteristics of isolated bacteria

\begin{tabular}{|c|c|c|c|c|c|c|c|c|c|}
\hline \multicolumn{10}{|c|}{ Biochemical tests } \\
\hline Strain no & Catalase & Indole & Starch & Ammonia & Eijkman & Urease & Carbohydrate & Amylase & VP \\
\hline BMI & + & + & + & + & + & - & + & + & - \\
\hline BM2 & + & - & - & + & + & - & - & + & + \\
\hline BM3 & + & + & + & - & - & + & + & - & + \\
\hline DI & + & + & + & + & + & + & + & - & + \\
\hline D2 & + & + & + & + & + & - & + & + & - \\
\hline D3 & + & + & + & + & + & + & - & + & - \\
\hline D4 & + & + & + & - & + & + & + & + & - \\
\hline $\mathrm{C} 2$ & + & - & + & + & + & + & - & + & - \\
\hline $\mathrm{C} 3$ & + & + & + & + & + & + & - & - & - \\
\hline
\end{tabular}

$+=$ Positive; -=Negative

\section{Optimization of growth conditions}

In the present investigation, the growth of isolated strains was observed in various growth media like NA, ACDA and BCDA. It was seen that the basic czapek dox agar (BCDA) was suitable for massive growth of BM3, D1, C2 and Nutrient agar (NA) medium was suitable for massive growth of BM1, BM2, D2, D3, D4, C3.

In this experiment, the bacterial cultures of 9 strains were incubated at different temperatures like $25,29,34,37$ and $40^{\circ} \mathrm{C}$. The optimum growth of all the strains was found in $37^{\circ} \mathrm{C}$. The optimum temperature range for bacteria is from about $25-36^{\circ} \mathrm{C}$. A great number of bacteria may grow quite well over the temperature $10^{-40} \mathrm{C} .{ }^{6}$ Sultana ${ }^{17}$ observed that $33 \pm 4^{\circ} \mathrm{C}$ temperatures was ideal for the growth of bacteria. ${ }^{17}$ Certain bacteria develop most vigorously at temperatures below $20^{\circ} \mathrm{C}$. Thermophiles grow well at temperatures $45-65{ }^{\circ} \mathrm{C}$ and some thermophiles are incapable of multiplying below $40^{\circ} \mathrm{C} .{ }^{1}$

The strains obtained in this study were incubated for different incubation periods $(6,12,24,36,48$ and $72 \mathrm{~h})$. Incubation period of 24h was suitable for BM1, BM2, D2, D3, D4, C3 while BM3, D1 and $\mathrm{C} 2$ was found to be suitable with incubation period of $36 \mathrm{~h}$.
Coliform bacteria grow in the incubation period of $24 \pm 2 \mathrm{~h}$ and at $32^{\circ} \mathrm{C}$ and it shows good growth at $37^{\circ} \mathrm{C}$ for $48 \mathrm{~h}$ of incubation. In visual observation, it was found that after $24 \mathrm{~h}$ of incubation, the colour of BM2 was light orange, BM1 was white and BM3 was creamy white in their preferred medium (BCDA and NA). After 48-72h of incubation, the color of BM2 was orange, BM1, D1 were yellow, C2 was red and BM3, D2, D3, D4, C3 remained creamy white. The colony types of BM1, BM2, D2 and D4 strains were wet and the rest were creamy. Staphylococci and Micrococci produce golden brown, yellow or white colony on ordinary media. Some Enterococci, Coryneforms and Enterobacteria may produce black colonies on ordinary media. ${ }^{8}$

\section{Antagonism assay}

Cross streaking method was employed to determine the antagonism among the bacterial strains for their future application in different aspects. Details of the antagonism within the bacterial isolates are described (Table 3).

BM2 has antagonism with all the other strains so it is not possible to develop a consortium using this strain as one of the isolates. D1, D3 also have antagonism with most of the other strains. BM1 is the 
most potent strain as it has antagonism with none of the other isolates. BM3, D2, D4, D5 and D6 have antagonism with a few isolates and these strains along with BM1 can be tested in different combinations for preparing consortium.

\section{Heavy metal tolerance assay}

Five heavy metals (As, $\mathrm{Zn}, \mathrm{Pb}, \mathrm{Hg}, \mathrm{Cd}$ ) were selected for determination of metal tolerance capability of the isolated bacterial strains (BM1, BM2, BM3, DF1, D2, D3, D4, C2, C3). The tolerance test indicated that among five experimented heavy metals, maximum

Table 3 Antagonism within the isolated bacteria

\begin{tabular}{llllllllll}
\hline \multicolumn{1}{c}{ Antagonism } & & & & & & & & & \\
\hline Strain no & BMI & BM2 & BM3 & DI & D2 & D3 & D4 & C2 & C3 \\
\hline BMI & $\times$ & + & - & - & - & + & - & - & - \\
BM2 & + & $\times$ & + & + & + & + & + & + & + \\
BM3 & - & + & $\times$ & - & - & - & - & - & - \\
D1 & - & + & - & $\times$ & + & + & + & + & + \\
D2 & - & + & - & + & $\times$ & - & - & - & - \\
D3 & + & + & - & + & - & $\times$ & + & + & - \\
D4 & - & + & - & + & - & + & $\times$ & - & - \\
C2 & - & + & - & + & - & + & - & $\times$ & + \\
C3 & - & + & - & + & - & - & - & + & $\times$ \\
\hline
\end{tabular}

+ = antagonism present; -=antagonism absent

Table 4 Metal tolerance of isolated bacterial strains

\begin{tabular}{lllllll}
\hline \multicolumn{7}{l}{ Inhibitory concentration (ppm) } \\
\hline Strain no & $\mathbf{A s}^{3+}$ & $\mathbf{A s}^{\mathbf{5}}$ & $\mathbf{Z n}$ & $\mathbf{P b}$ & $\mathbf{H g}$ & $\mathbf{C d}$ \\
\hline BMI & 285 & 350 & 200 & 3750 & 200 & 30 \\
BM2 & 260 & 300 & 300 & 3000 & 285 & 15 \\
BM3 & 250 & 320 & 280 & 4000 & 300 & 20 \\
D1 & 255 & 345 & 270 & 3650 & 220 & 15 \\
D2 & 270 & 325 & 260 & 3500 & 250 & 10 \\
D3 & 265 & 300 & 275 & 3550 & 280 & 20 \\
D4 & 260 & 315 & 215 & 3450 & 275 & 25 \\
C2 & 275 & 340 & 225 & 3700 & 270 & 10 \\
C3 & 280 & 330 & 210 & 3650 & 260 & 15 \\
\hline
\end{tabular}

MIC was noted when the isolates failed to grow on plates even after 10days of incubation. ${ }^{18}$ Mergeay et al. ${ }^{19}$ tested the minimal inhibitory concentrations (MICs) of several different metals and found the most toxic metal (with the lowest MIC) was mercury whereas the least toxic metal was manganese. ${ }^{19}$ The microbial tolerance at each concentration of heavy metal was depicted by the cup assay test. The diameter of inhibition zone around each cup increased with the increase in concentration of heavy metals indicating toxic effect of the heavy metals on the growth of microorganisms. The Barrackpore Municipality and Dhapa waste dumping site collects all the domestic as well as industrial solid waste of the Barrackpore city, Kolkata city, respectively and its surrounding areas. The waste coming from domestic and industrial sources is the appropriate environment where the microorganisms can develop resistance to heavy metals. The presence of small amount of heavy metals in the solid waste can induce the emergence of heavy metal resistant microorganisms. The microbial resistance to heavy metal is attributed to a variety of among heavy metal resistant bacteria. ${ }^{21}$

\section{Antibiotic sensitivity assay} activity. tolerance was shown to $\mathrm{Pb}$ showing the growth of microorganisms up to $4000 \mathrm{ppm}$ and minimum tolerance to $\mathrm{Cd}$ showing no growth above 30ppm. MIC was noted when the isolates failed to grow on plates even after 10days of incubation. The result shows that for all the three bacteria the MIC ranged from $250 \mathrm{ppm}$ to $350 \mathrm{ppm}$ for As, $\mathrm{Cd}$ (10-30ppm), Zn (200-300ppm), Hg (200-300ppm) and Pb (30004000ppm) (Table 4). In the present study, highest tolerance of As and $\mathrm{Cd}$ found in BM1 while highest $\mathrm{Zn}$ tolerance is observed in BM2 and $\mathrm{BM} 3$ showed maximum $\mathrm{Hg}$ and $\mathrm{Pb}$ accumulation. In our study the most toxic metal (with the lowest MIC) is cd whereas the least toxic metal tested is $\mathrm{Pb}$ (Table 4).

detoxifying mechanism developed by resistant microorganisms such as complexation by exopolysaccharides, binding with bacterial cell envelopes, metal reduction, metal efflux etc. These mechanisms are sometime encoded in plasmid genes facilitating the transfer of toxic metal resistance from one cell to another. ${ }^{20}$ The heavy metal resistant organism could be a potential agent for bioremediation of heavy metals pollution. Since heavy metals are all similar in their toxic mechanism, multiple metal tolerances are common phenomena

Antibiotic sensitivity test helps to determine how effective an antibiotic is against the test organism. The 9 isolates were screened for its sensitivity towards four antibiotics and the result is noted (Table 5). Antimicrobial compounds are produced by most of the isolates which can serve medical science. D1, D3 and D5 showed no antimicrobial 


\section{Antimicrobial activity assay}

Production of antimicrobial compounds seems to be a general phenomenon for most bacteria. In the present study 3 isolates showed antibacterial activity and 5 isolates showed antifungal activity, but 3 isolates showed neither antibacterial nor antifungal activity against the pathogens. The result has been depicted (Table 6). Similar study was reported by Subramaniam et al. ${ }^{22}$ A variety of antimicrobial compounds are produced by members of the genus Bacillus, many of these identified as peptides, lipopeptides and phenolic derivatives. Search for novel secondary metabolites with diverse biological activity in assorted environment has gained greater attention in recent years.

\section{Extracellular enzyme production}

With the growing awareness on environmental protection, the use of enzymes, particularly from extremophiles, gained considerable attention in many industrial processes. In recent years, the microbial enzymes have been replacing chemical catalysts in manufacturing chemicals, textiles, pharmaceuticals, paper and food agricultural chemicals. Enzyme based industrial bioprocess now directly competes

Table 5 Antibiotic sensitivity of bacterial strains with established chemical based process. However in this study, the 9 isolates were subjected to qualitative assay for production of eight different enzymes such as protease, lecithinase, DNase, lipase, cellulase, amylase, catalase and oxidase. Similar study was reported by Subramani and Narayanasamy. ${ }^{23}$ Interestingly in our study 6 of them showed production of protease enzyme which has a high market value. All the 9 strains produced catalase and oxidase enzyme. The result is noted (Table 7).

\section{Protease assay}

6 strains (BM1, BM3, D1, D3, C2 and C3) among the 9 isolates exhibited protease production. Protease having a wide spread application in food industry, detergent industry, pharmaceuticals as well as in solid waste degradation, quantitative assay of the protease produced was carried out. The activity of the protease enzyme thus produced was determined and the result was expressed in IU/ml. The result is depicted (Table 8 ). The quantitative assay of protease invariably proved that among the 6 strains, BM1 is producing protease with high titer value and Gupta et al., ${ }^{24}$ similarly reported alkaline protease production from bacterial species and its industrial application.

\begin{tabular}{lllll}
\hline \multicolumn{7}{l}{ Antibiotics concentration(100ppm) } \\
\hline Strain No & Gentamycin & Oxytetracycline & Penicillin & Streptomycin \\
\hline BMI & + & - & - & + \\
BM2 & + & + & + & + \\
BM3 & + & - & + & + \\
DI & + & + & + & + \\
D2 & + & + & + & + \\
D3 & + & + & - & + \\
D4 & + & + & - & + \\
C2 & + & - & + & + \\
C3 & + & + & + & + \\
\hline
\end{tabular}

+=growth inhibited; -=growth not inhibited

Table 6 Antimicrobial activity of the bacterial strains

\begin{tabular}{lllll}
\hline \multicolumn{7}{l}{ Antibiotics concentration $(100 \mathrm{ppm})$} \\
\hline Strain No & Gentamycin & Oxytetracycline & Penicillin & Streptomycin \\
\hline BMI & + & - & - & + \\
BM2 & + & + & + & + \\
BM3 & + & - & + & + \\
DI & + & + & + & + \\
D2 & + & + & + & + \\
D3 & + & + & - & + \\
D4 & + & + & - & + \\
C2 & + & - & + & + \\
C3 & + & + & + & +
\end{tabular}

+ = antimicrobial activity present; - = antimicrobial activity absent

Table 7 Qualitative assay for enzyme production

\begin{tabular}{lllll}
\hline \multicolumn{2}{l}{ Antibiotics concentration $(100 \mathrm{ppm})$} & & \\
\hline Strain No & Gentamycin & Oxytetracycline & Penicillin & Streptomycin \\
\hline $\mathrm{BMI}$ & + & - & - & + \\
$\mathrm{BM} 2$ & + & + & + & + \\
$\mathrm{BM} 3$ & + & - & + & + \\
\hline
\end{tabular}


Table Continued.

\begin{tabular}{lllll}
\multicolumn{4}{l}{ Antibiotics concentration $(100 \mathrm{ppm})$} & \\
\hline Strain No & Gentamycin & Oxytetracycline & Penicillin & Streptomycin \\
\hline DI & + & + & + & + \\
D2 & + & + & + & + \\
D3 & + & + & - & + \\
D4 & + & + & - & + \\
C2 & + & - & + & + \\
C3 & + & + & + & + \\
\hline
\end{tabular}

\section{Waste degradation potential by isolated bacteria}

Protease enzyme has vast application in degradation of waste. Thus the 6 strains capable of producing protease enzyme were subjected to waste degradation efficiency test. In our study it can be observed that BM1 has the highest degradation potential followed by $\mathrm{BM} 3 . \mathrm{BM} 1$ is also a potent protease enzyme producer thus it possess better degradation ability too (Figure 1). As the waste is break down by microorganisms (bacteria), weight of the litter decreases. In the present study of decomposition, we observed that the weight of treated litter decreased because bacteria broke it down and converted it to simple molecules. Percentage of weight loss of waste samples were increased with the progression of decomposition process as can be seen in Figure 1. Similar observation was reported by Zaved et al., ${ }^{25}$ on weight loss study of garbage by specific bacteria in Bangladesh. In our study it can be observed that BM1 has the highest degradation potential followed. Thus BM1 can be efficiently used for bioremediation of solid waste.

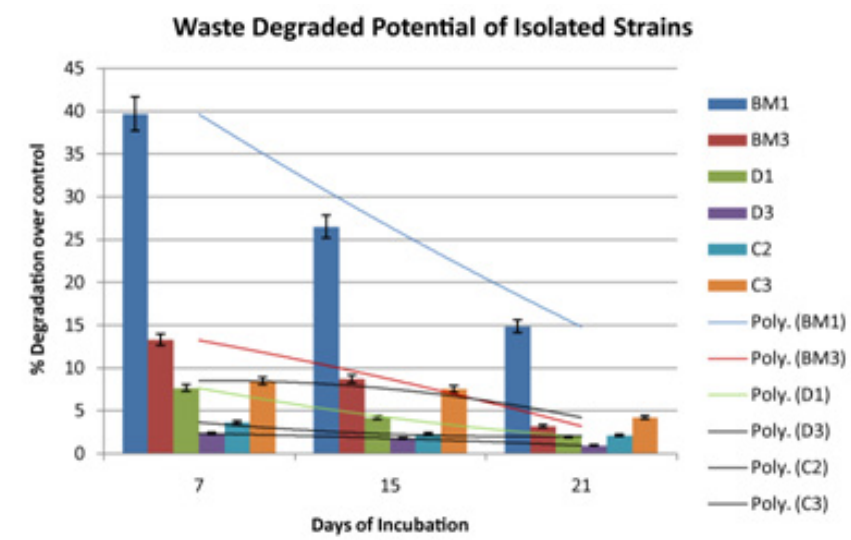

Figure I Waste degradation potential of the isolated strains.

Table 8 Activity of protease produced by the bacterial strains

\begin{tabular}{ll}
\hline Strain no & Activity in IU/mI \\
\hline BMI & 17233.40 \\
BM3 & 3693.29 \\
DI & 796.21 \\
D3 & 126.35 \\
C2 & 366.21 \\
C3 & 401.20 \\
\hline
\end{tabular}

\section{Conclusion}

Municipal solid waste is a combination of different substrates thus it is an ideal enrichment media for cultivation of numerous microorganisms. Bacteria in this environment are metabolically active which leads to the production of various enzymes and bioactive compounds compared to other environmental condition. Therefore, it is important to understand the waste derived bacteria in ecological terms and also as a resource for biotechnology. Our present study evidently revealed that municipal waste dump site is a potential source for wide spectrum of antimicrobial and industrial enzyme producing bacteria. Moreover it can be an imperative resource for bio prospecting novel/ rare species which could yield valuable bioactive molecules necessary for eco friendly degradation of waste and can also act as a good substitute in chemical processes in industry.

\section{Acknowledgements}

None.

\section{Conflict of interest}

Author declares that there is no conflict of interest.

\section{References}

1. Alexander M. Introduction to soil microbiology. 2nd ed. New York: John Wiley and Sons Inc; 1997.

2. American Wood Preservers Association Standards. Books of standards, Stevensville, Maryland, USA; AWPA. 1986.

3. Walkey A, Black IA. An examination of the Degtjareff method for determining soil organic matter and a proposed modification of the chromic acid titration method. Soil Science. 1934;37(1):29-38.

4. Bremner JM. Determination of nitrogen in soil by the Kjeldahl method. Journal Agricultural Science. 1960;55(1):11-33.

5. Jackson ML. Soil Chemical Analysis. 1st ed. New Delhi: Prentice Hall of India Pvt. Ltd.; 1973.

6. Williams ST, Cross T. Actinomycetes, methods in microbiology. New York: Academic Press; 1971

7. Pacarynuk LA, Danyk HC. Biochemical Tests. In: Principles of Microbiology, Laboratory Manual. USA: Spring, TX; 2004:28-34.

8. Collins CH, Lyne PM, Grange JM. Microbiological Methods. 6th ed. Butterworth, London; 1989.

9. Gillers RR, Govan JRW. Typical of Pseudomonas pyocyanea by pyocine production. J Path Bact. 1966;91:33.

10. Govan JRW, Gillies RR. Further studies in the pyocine typing of Pseudomonas pyocyanea. J Med Microbial. 1969;2(1):17-25.

11. Cooper KE. Theory of antibiotic inhibition zones in agar media. Nature. 1955;176(4480):510-511.

12. Nakano MM, Zuber P. Molecular biology of antibiotic production in Bacillus. Crit Rev Biotechnol. 1990;10(3):223-240.

13. Mohawed SM, Kassim EA, Shahed AS. Studies on the effect of different $\mathrm{pH}$ values, vitamins, indoles and gibberellic on the production of lipase by Aspergillus althecias. Agric. Wastes. 1986;17(4):307-312. 
14. Patil M, Shastri NV. Extracellular proteases by Alternasia alternater (Fr.). J Ferment Technol. 1981;59(5):403-406.

15. Berkeley RCW, Campbelt R. Microbial nutrition and the influence of environmental factors on microbial growth and other activities. In: Microorganism: function, form and environment. In: Hawker LE, Linton AH editors. London: Edward Arnold Publisher limited; 1972.

16. Krishnamourthy RV, Vajranabhiah SN. Biological activities of earthworm casts. An assessment of plant growth promoter levels in the casts. Anim Sci. 1986;95:341-351.

17. Sultana S. Isolation of cellulolytic microorganisms and their activities. M. Phil. Thesis Institute of Biological Science, University of Rajshahi Bangladesh, Bangladesh; 1997.

18. Haq R, Zaidi SK, Shakoori AR. Cadmium resistant Enterobacter clacae and Klebsiella sp isolated from industrial effluents and their possible role in cadmium detoxification. World Journal of Microbiology and biotechnology. 1999;15(2):283-290.

19. Meargeay M, Nies D, Schlegel HD, et al. Alcaligenes eutrophus CH34 is a facul-tative chemolithtroph with plasmid-borne resistance to heavy metals. J Bacteriol. 1985;162(1):328-334.
20. Silver S. Bacterial resistances to toxic metals- a review. Gene. 1996;179(1):9-19.

21. Rajbanshi A. Study on heavy metal resistant bacteria in guheswori sewage treatment plant. Our Nature. 2008;6(1):52-57.

22. Joerger RD, Sabesan S, Visioli D, et al. Antimicrobial activity of chitosan attached to ethylene copolymer films. Packaging Technology and Science. 2009;22(3):125-138.

23. Ramesh S, Mathivanan N. Screening of marine actinomycetes isolated from the Bay of Bengal, India for antimicrobial activity and industrial enzymes. World Journal of Microbiology and biotechnology. 2009;25(12):2103-2111.

24. Gupta R, Beg QK, Lorenz P. Bacterial alkaline proteases: molecular approaches and industrial applications. Appl Microbial Biotechnol. 2002;59(1):15-32.

25. Zaved HK, Rahman MM, Rahman MM, et al. Isolation and characterization of effective bacteria for solid waste degradation for organic manure. KMITL Sci Tech J. 2008;8(2):844-855. 